\title{
Formation of Technological Platforms in Mining Regions as a Tool for the Implementation of the National Technology Initiative (on the Example of the Kemerovo Region, Krasnoyarsk Territory and the Republic of Tatarstan)
}

\author{
Evgeniya Shavina, ${ }^{1, *}$ \\ ${ }^{1}$ Plekhanov Russian University of Economics, Academic Department of Political Economy and \\ History of Economic Science, 117997, Moscow, 36 Stremyanny lane, Russia
}

\begin{abstract}
At present, it is important for national economies to adapt to the emerging conditions of volatility. One of the main trends in the modern world is the transition to a new technological order. Therefore, it is important to build the economic system of any state on the basis of current trends. Taking into account the potential of the fuel and energy complex of the Russian Federation as a whole, and of its individual regions in particular, it is advisable to renew such sub-industries as the extractive industry. Modernization based on the use of new technologies in such a large sector of the economy has significant prospects in the context of the implementation of the National Technology Initiative. One of the tools contributing to innovative development is the formation of technology platforms. Regions can show different rates of involvement in the process of technological renewal due to the different level of the formed scientific and technical base and resource potential. Nevertheless, the centralized concentration of innovations, scientific resources and modern infrastructure are designed to have a positive impact on the subjects, regardless of the degree of influence of internal factors.
\end{abstract}

\section{Introduction}

Forecasts of the technological development of the world economy indicate that in the shortand long-term natural resources, energy, information technology, energy and resource conservation technologies, human resources and territory will remain as the main factors of economic development. Over time, the reliance of the Russian economy in general and of a number of regional economies in particular on the raw materials sector, that is based on extensive production technologies, will contribute to a decrease in the level of the country's competitiveness in the world economy. In this context, it is fundamentally important to pay considerable attention to the introduction of new technologies in traditional industries at the regional level and to use the most effective tools that increase the level of innovative

\footnotetext{
* Corresponding author: evgeniyashavina@gmail.com
} 
development of the economies of both individual regions and the country. Moreover, it is important to form an integrated approach to solving the problems of innovative modernization within the regions themselves. The rationalization of the technological approach in the extractive industries is intended to update the activities of the existing production base, to effectively master the resource potential, to contribute to the development and implementation of a system model for the use of technological innovations, by organizing on co-operative lines the spheres of the state, society, business and science [1]. For this reason, it is extremely relevant to develop technological platforms at the regional level within the framework of the National Technology Initiative projects. These platforms are not only able to become a driver of scientific and technological development of traditional industries in the regions, but also to ensure the achievement of technological sovereignty in the long term, which is especially important in the framework of the implementation of the import substitution policy and the prospects for cooperation in the format of integration groups.

\section{Materials and Methods}

The National Technology Initiative (NTI) is a long-term comprehensive program creating conditions for ensuring leadership of Russian technological companies in new hi-tech markets that will determine the structure of the world economy in the next 15-20 years [2]. It is reasonable to examine the development of this initiative in those sectors of the national economy that have potential, as well as an already established (at least to some extent) production base. One of such sectors is the fuel and energy complex (FEC). According to the categorization of NTI markets, energy corresponds to category 1 - markets that require expensive infrastructure and, as a result, a large share of state participation.

The prospects of the fuel and energy complex are closely linked to the introduction of new technologies for the exploration and production of minerals, their efficient processing, as well as with the rationalization of energy extraction from the obtained resources by introducing new technologies and scaling of the"green" energy share. Here we are talking not only about new technical developments, but also about the improvement of the technology itself at all stages of the process: from exploration of deposits to the delivery of energy to consumers. For this reason, Energinet is the market which is strategically important for the fuel and energy complex of the future. This is the market for equipment, software, engineering and services for various-scale integrated systems and services of smart energy [2]. The need for a significant level of state participation in this market is justified, firstly, by the scale of the sector itself. It would thus be irrational to entrust the transformation to the self-regulation algorithm within the framework of market relations. Secondly, 1st market category is characterized by the lack of expensive infrastructure. Searching for investors in this context may require time resources, which are scarce due to the rapid pace of the energy transition. Untimely actions in this matter may lead to the catching-up development of the fuel and energy complex, which is disadvantageous for Russia's position in the world energy markets. Thirdly, the participation of the state is also necessary in terms of coordinating various types of resources and stimulating activity in the interaction of spheres that directly affect the improvement of the technological base and the development of new approaches in the fuel and energy complex. One of the effective steps to stimulate and achieve such interaction is the creation of technological platforms [3]. Technological platforms are a communication tool aimed at enhancing efforts for creating promising commercial technologies, new products (services), attracting additional resources for research and development based on the participation of all stakeholders (business, science, government, civil society), improving regulatory and legal framework in the field of scientific and technological, innovative development. It is reasonable to begin the formation of this type of systems locally, that is, by testing them at the regional level [4]. The problem of technological 
development of regions was considered by J. Schmutzler and E. Lorenz on the example of 28 regions from seven developing countries of Latin America [5]. They studied the influence of the spatial structure of economic activity on the susceptibility of business to knowledge, the development of new products or technologies. The factors of the technological development of Russian regions are examined in the works of V.V. Martemyanov, V.V. Pechenkina [6], D.E. Tolmachev, K.V. Chukavina [7], N. Davidson, O. Mariev, A. Pushkarev [8]. These problems in the field of fuel and energy complex were considered by S.M. Nikitenko, E.V. Goosen [9], R.V. Gulidov [10], V.A. Tsybatov [11-13] and others.

Based on the experience of various researchers, one should consider regions with different levels of innovation and scientific activity for a more comprehensive analysis. That is because despite the specific nature of the developed sectors of the fuel and energy complex, which is the basis of the Russian economy, related branches, specifically scientific, act as a catalyst for development. To determine the possibility of introducing technological platforms it is necessary to assess the economic, scientific and technological base potential of the regions. In order to do that 3 constituent entities of the Russian Federation were analyzed: the Kemerovo Region, the Krasnoyarsk Territory and the Republic of Tatarstan. The main selection criterion was the relatively equal share of the extractive industry in the structure of the economies of these regions combined with different levels of investment in science and the introduction of innovative technologies. These differences allow us to analyze and compare the role of the primary spheres for the formation of technological platforms in increasing the indicators of the fuel and energy complex by region. Thus, the share of the extractive industry takes more than $1 / 4$ of the GRP of the regions under consideration (Table 1 - composed by [14]). It is interesting to note that the leading region has changed over the course of 3 years. In 2017 the Kemerovo region ranked 1st with a share of the mining industry taking up 35.2\% in the GRP structure, then in 2019 the Republic of Tatarstan took the leading role with a share of $28.7 \%$.

Table 1. The share of the extractive industry in the structure of the gross regional product, $\%$.

\begin{tabular}{|c|c|c|c|}
\hline Region / period & $\mathbf{2 0 1 7}$ & $\mathbf{2 0 1 8}$ & $\mathbf{2 0 1 9}$ \\
\hline Kemerovo region & 35.2 & 35.9 & 26.3 \\
\hline Krasnoyarsk krai & 20.3 & 24.6 & 22.4 \\
\hline Tatarstan Republic & 23.7 & 28.7 & 28.7 \\
\hline
\end{tabular}

Let us take a closer look at the characteristics of each of the regions under consideration.

Kemerovo Region (Kuzbass) is located in the southeast of Western Siberia. Availability of resources ant their use in the Kemerovo region can sustain the positive dynamics of the socio-economic development of the region in the long term. However, access to the exploitation of valuable minerals (manganese, quartzite, dolomite, fluorite, phosphorite, graphite) will remain limited due to the ecological priorities for territories attractive for settlement and tourism. According to the data of the investment portal of the Russian regions for2019, the factors of the investment attractiveness of the region include:

- high labor potential (ranked 16th among the Russian regions and 3rd among the regions of the Siberian Federal District in terms of population);

- favorable investment climate (regional legislation is investor-oriented);

- the presence of priority development area (4 PDAs in Kuzbass);

- developed transport and logistics infrastructure (2 international airports, long length and density of railways); 
- high economic potential (ranked 1st for the diversity and development of minerals, the third largest energy system in the Siberian Federal District, the largest metallurgical and chemical complex in the Russian Federation).

The Krasnoyarsk Territory is the second largest constituent entity of Russia. It covers more than two thousand square kilometers. This is almost $14 \%$ of the total territory of the country. Mineral resources include oil, gas, iron ores, coal, non-ferrous and also the rare metals. There are more than 1200 deposits to date in this region. More than 30 hydrocarbon deposits are located in the Krasnoyarsk Territory. There is an active production of oil and gas. It should be noted that the region ranks first in Russia in terms of total geological coal reserves. About $70 \%$ of the raw materials produced in the country are sold here. The region ranks first in Russia in terms of timber reserves, second in terms of hydropower resources, and third in terms of reserves of mineral fuel (mainly brown coal, oil reserves have been discovered).

The energy complex of the region located in the Volga Federal District - the Republic of Tatarstan is the basis for the development of almost all sectors of the economy in the region. It satisfies the needs of the republic in electrical and thermal energy and is the energy base of large oil production, oil refining, petrochemical and other areas of the fuel and energy complex located in the republic. The region has significant reserves of hydrocarbon resources, but there are also others: coal and brown coal, copper and bauxite, oil shale and peat, as well as raw materials for the construction industry (limestone, dolomite, clay, etc.). According to the data of the investment portal of the Russian regions for 2019, the investment attractiveness of the Republic of Tatarstan is based on the following factors:

- ranked 2 nd in the national rating of the investment climate among the constituent entities of the Russian Federation;

- developed investment infrastructure: 2 IES and 5 PDAs;

- favorable geographic location: many large political, economic and industrial centers of Russia are located within a radius of 1 thousand $\mathrm{km}$.;

- high industrial potential.

It is important to note that all the regions under consideration specialize on the extraction of various types of minerals. They are quite developed from the point of view of the conventional technology application, but they are contrasting from the point of view of innovative activity and corresponding investments in new technologies, which are the basis for the transition to a new technological order. This is primarily reflected in the GRP, which allows us to characterize the final result of the production activity of all economic units (figure 1 - composed by [15].).

GRP of the regions, rub.

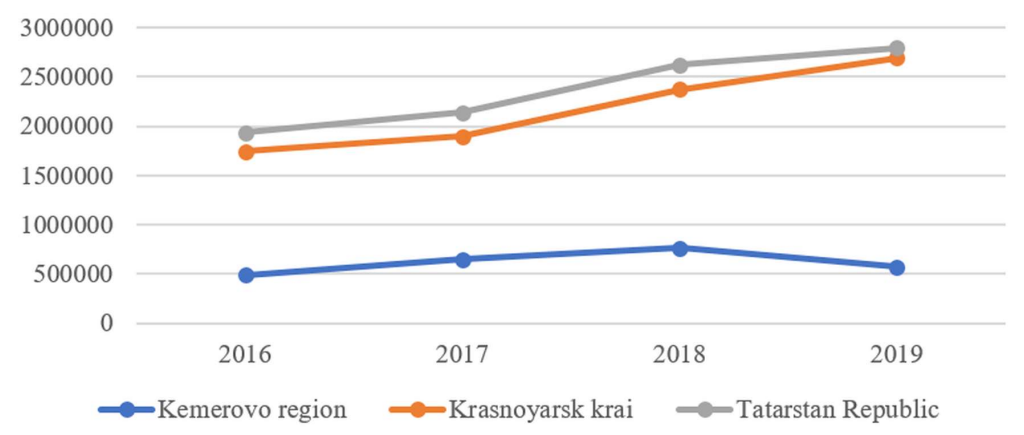

Fig. 1. Dynamics of the regional product gross (of the Kemerovo Region, the Krasnoyarsk krai, the Republic of Tatarstan from 2016 to 2019, rub. 
The change in the share of the mining sector in the Republic of Tatarstan and the Krasnoyarsk Territory by 2019 improved the dynamics of the GRP of both regions. Tatarstan retained its leading positions, but the Kemerovo region, despite the first rankings in the extraction of various types of minerals in the Kuznetsk basin, by 2019 moved to the last place among the three subjects under consideration. Why did it happen? The answer to this question can be found by analyzing the dynamics of indicators that contribute to energy transition, as well as being the basis for the formation and functioning of technological platforms in the energy sector. Let us study the regional development and use of advanced production technologies in general (table 2 - composed by [15]).

Table 2. Number of advanced production technologies, which were developed and used in the considered regions of the Russian Federation for the period from 2016 to 2020, units.

\begin{tabular}{|c|c|c|c|c|c|c|}
\hline Region & $\begin{array}{c}\text { Advanced } \\
\text { production } \\
\text { technologies, } \\
\text { units }\end{array}$ & $\mathbf{2 0 1 6}$ & $\mathbf{2 0 1 7}$ & $\mathbf{2 0 1 8}$ & $\mathbf{2 0 1 9}$ & $\mathbf{2 0 2 0}$ \\
\hline \multirow{2}{*}{$\begin{array}{c}\text { Kemerovo } \\
\text { region }\end{array}$} & developed & 30 & 33 & 23 & 20 & 56 \\
\cline { 2 - 7 } & used & 3064 & 3219 & 3507 & 3563 & 3365 \\
\hline \multirow{2}{*}{$\begin{array}{c}\text { Krasnoyarsk } \\
\text { krai }\end{array}$} & developed & 35 & 31 & 46 & 38 & 30 \\
\cline { 2 - 7 } & used & 3751 & 3787 & 3922 & 4275 & 3932 \\
\hline $\begin{array}{c}\text { Tatarstan } \\
\text { Republic }\end{array}$ & developed & 64 & 57 & 43 & 54 & 65 \\
\cline { 2 - 7 } & used & 7355 & 7648 & 7694 & 8304 & 7178 \\
\hline
\end{tabular}

The Republic of Tatarstan has been a leader over the past 5 years: the number of technologies used is more than 2 times greater than that of the Kemerovo Region and almost 2 times more than that of the Krasnoyarsk Territory. In terms of the number of technologies developed, the Republic of Tatarstan also occupies a leading position. This data indicates the great level of the region's involvement in improving the manufacturability of its industries, which means that the conditions that have formed at the moment in the republic are most favorable for the formation of technological platforms. The Kemerovo region ranks last in terms of GRP despite the existing potential for the use of technologies. However, the region in 2020 began to be actively involved in the development of technologies, which, from the point of view of the formation of a new type of economy and the transition to a new technological structure, can be characterized as a positive trend. Note that there was an increase in the rate of use of advanced technologies in all regions up to 2019, and in 2020 this figure decreased. This may be due to the change in the vector of technological development in favor of the developed production technologies.

Availability of highly qualified personnel and the support of the scientific sector is one of the most important prerequisites for the formation of technological platforms in the regions. So, for example, in the Kemerovo region there is an outflow of scientific personnel, the Republic of Tatarstan has a positive vector, and the Krasnoyarsk Territory has slightly increased the number of people engaged in scientific research and development (figure 2 composed by [15]). 


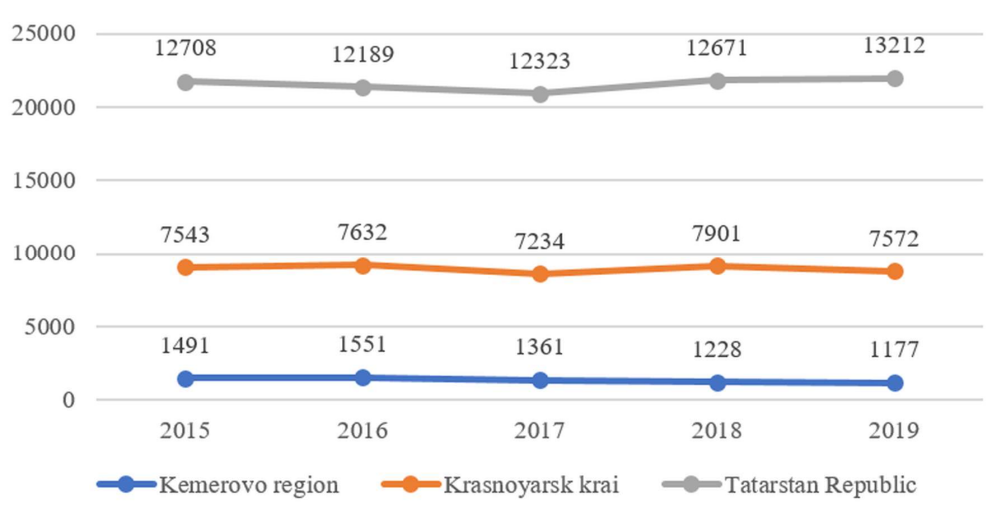

Fig. 2. Number of personnel involved in research and development in the certain regions, people.

Regional investment in research and development confirms current trends. Thus, in regions that showed an increase in the number of personnel in the scientific sector, the share of research costs increased to a much greater degree during the period under review than in the Kemerovo region, which has a negative trend (figure 3 - composed by [15]).

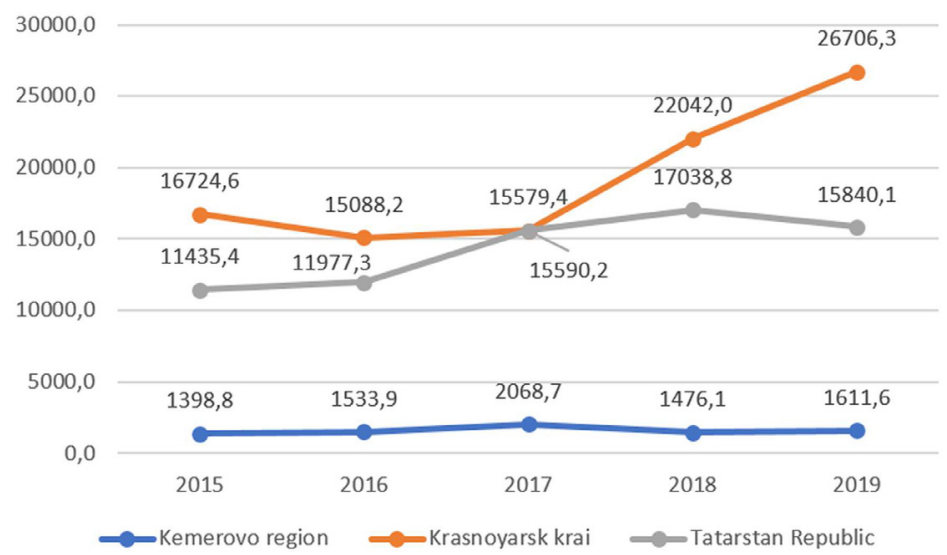

Fig. 3. Internal operating costs for research and development, million rubles.

This trend indicates the relative unpreparedness of this region to the formation of efficiently functioning technological platforms, since the funding vector is still shifted in favor of other spheres, instead of scientific, which is fundamentally important for the development of intensive production technologies.

\section{Results and Discussion}

Thus, activity in the field of forming fundamental components for the innovative development of the power plant is directly related to investments in its scientific component. The positive dynamics in the development of the Republic of Tatarstan, which is the leader in the indicators considered, is due to its high innovation activity, which directly affects the potential efficiency and ease of forming a technology platform in the region or its inclusion in a similar but larger system. At the same time, the Kemerovo region in this issue is rather a lagging entity, despite the fact that the share of extractive industry in GRP corresponds to the indicators of Tatarstan, and the number of new production technologies developed is 
greater than in the Krasnoyarsk region. Speaking about Krasnoyarsk region, we note that if the pace of innovation development is maintained and there is no incentive to use the scientific and technical potential of the region, there is a risk of a slowdown in its development.

It should be noted that at the moment there is no information about the affiliation of the actors in question to any developing technological system of cooperation. Rather, there are single projects in the energy sector, implemented in the regions and unrelated directly to the extractive industry. Thus, in the future from the point of view of the introduction of new technologies, Tatarstan is undergoing a digital transformation of Kazan CHP-3, where the complex modernization and introduction of a new power unit has been completed. Information technologies, including artificial intelligence and robotics, and oil workers are actively introducing. In particular, Tatneft company is working to create "digital twins" of all fields. With the help of such constantly operating geological-hydrodynamic 3D models it is possible to predict various variants of oil development of objects. However, these are only local projects, which so far represent only the potential for the formation of a full-fledged regional or even interregional technological cooperation.

With increased international competition and the pace of scientific and technological progress, external interregional relationships are key, providing access to ideas, knowledge and technologies that cannot be obtained within the limited space of the region [16]. World experience shows that the most effective way to improve the competitiveness of companies is to specialize in research and high technologies [2]. The need to form developed technology platforms in the Russian Federation is relevant due to the prospect of embedding them in Eurasian technology platforms. Thus, participation in the Eurasian technology platform "Solid Mineral Mining and Processing Technologies" may be important for the regions under consideration [17]. Russian regions can become agents of cooperation in the scientific, technical and innovative areas of the development of mining activities of the EAEU member states. And in building up domestic capacity within Eurasia, the efficiency of solid mining and processing will be improved and the foundations for the energy transition will be laid.

The second technology platform on which these regions, due to the specifics of their industries, should be relied upon is "Environmental Development Technologies" [18]. Since for the successful operation of the power plant of the regions and the country as a whole, green energy technologies must be combined with traditional energy sources, even if their level of technology increases. This is especially true for the Kemerovo region, whose resource potential is mainly realized in non-environmental ways. But it is worth mentioning that there is an investment project "Clean Energy" in the region, providing for the creation of a network of electric charging stations, which indicates that the subject is taking initiatives related to energy ecology. Also, in this aspect it is worth paying attention to the successful combination of technologies in the region-leader - the Republic of Tatarstan. Thus, the country is working on the development of renewable energy sources, including wind and solar energy [19]. For example, Yadran Solar plans to start production of solar modules in the city. And at three sites (in Kamsk-Ustina, Rybno-Slobod and Spassky districts) studies of wind conditions were organized using specialized wind measurement devices.

\section{Conclusion}

Thus, Russia has every chance to secure itself a technological leadership in the fuel and energy complex, including the extractive industry. However, the key issue is capacity building within the regions that are ready to introduce new technologies that are localized in enterprises and research institutions. In the future, the availability of a technological base and the regular introduction of new technologies in sectors strategically important for the Russian economy can make a significant contribution not only to the sustainable development of a 
new type of economy and reduce Russia's lag behind world technological leaders but can also contribute to strengthening of the integration processes within the EAEU.

\section{Acknowledgement}

This study was financed by a grant from the Plekhanov Russian University of Economics.

\section{References}

1. S.V. Kortov, D.B. Shulgin, D.E. Tolmachev, A.D. Egarmina, Economy of region, 13 (3), 935-947 (2017). DOI:10.17059/2017-3-24

2. Regional standard NTI, $2019 . \quad$ URL: https://nti2035.ru/docs/2019_Regstandart_NTI_methodrec.pdf

3. O.V. Maryina, Economic Sciences, 3(88), 116-123 (2012)

4. E.V. Onishchenko, S.V. Gordienko, Innovation economy issues, 10 (3), 1449-1466 (2020). DOI:10.18334/vinec.10.3.110691

5. J. Schmutzler, E. Lorenz, Industrial and Corporate Change, 20(6), 25 (2008)

6. V.V. Martemyanov, V.V. Pechenkina, Innovations, 8(118), 39-44 (2008).

7. D.E. Tolmachev, K.V. Chukavina, Economy of region, 16(2), 420-434 (2020).

8. N. Davidson, O. Mariev, A. Pushkarev, Foresight, 12(3), 62-72 (2018)

9. S.M. Nikitenko, E.V. Goosen, Economics and Management, 1, 27-32 (2017)

10. R.V. Gulidov, Spatial Economics, 3, 62-76 (2007)

11. V.A. Tsybatov, Regional economics: theory and practice, 27 (402), 36-52 (2015)

12. V.A. Tsybatov, I.A. Naugolnova, Journal of international economic affairs, 4, 30333044 (2019). DOI:10.18334/eo.9.4.41278.

13. V.A. Tsybatov, Economy of region, 14(3), 941-954 (2018). DOI:10.17059/2018-3-18

14. Structure of gross regional product (OKVED 2). URL: https://www.fedstat.ru/indicator/59450

15. Rosstat, Official website of the Federal State Statistics Service. URL: https://rosstat.gov.ru/

16. E. Shavina, V.Prokofev, E3S Web of Con., 174, 02014 (2020)

17. Passport of the Eurasian technological platform "Technologies for the extraction and processing of solid minerals". http://www.eurasiancommission.org/ru/act/prom_i_agroprom/dep_prom/SiteAssets/ET P-pasporta/Tverdie\%20iskopaemie.pdf

18. Passport of the Eurasian Technological Platform "Technologies for Environmental Development".

URL: http://www.eurasiancommission.org/ru/act/prom_i_agroprom/dep_prom/SiteAssets/ET $\mathrm{P}-$

19. RBC, Money from wind and sun: RT intends to develop "green" energy. URL: https://rt.rbc.ru/tatarstan/31/08/2020/5f4f4c3b9a7947ca5d882027 